\title{
Comparative study on inter-organizational cooperation in disaster situations and impact on humanitarian aid operations
}

\author{
Mizan Bustanul Fuady Bisri@
}

\begin{abstract}
Given the increased numbers of disasters and humanitarian crises which occur in the face of diminishing global resources, the contemporary disaster management and humanitarian fields face greater challenges to optimize cooperation and coordination processes among actors as well as in ensuring and increasing humanitarian aid delivery performance. This research, by using two case studies, will comparatively investigate inter-organizational cooperation and its performance on humanitarian operations during emergency response periods of the West Java Earthquake 2009 and the West Sumatera Earthquake 2009 in Indonesia. A combination of quantitative analysis, social network analysis (SNA), and qualitative analysis is used. SNA has been proven to be instrumental in modeling humanitarian actors' cooperation. In this research, humanitarian operation performance is analyzed in terms of its coherence, coverage, and connectedness. By categorizing results from the SNA in correlation with Gillmann's typology, it is proven that the networks in West Java fit the lead-agency type while in West Sumatra fit the lead-partnership type. In terms of performance, humanitarian operations in West Sumatra performed better in all three criteria compared to those in West Java. Based on the conclusions from this research, recommendations to improve cooperation and coordination among humanitarian actors in disaster situations have been made.
\end{abstract}

Keywords: Cooperation, Earthquake, Emergency, Humanitarian cluster, Social network analysis

\section{Introduction: contemporary discourse on cooperation in disaster and humanitarian crises}

The contemporary humanitarian and disaster management field faces several interrelated challenges and problems which make study on coordination and cooperation vital to save as many lives as possible and to lessen impacts. To begin with, there is a growing trend in the number and scale of disasters (UNISDR 2015; Cahill 2012), including that of climate-related and man-made disasters. During the first decade of this century alone, 4000 disasters occurred, significantly jumping from the 900 disasters during the 1970s (Brinkman 2010). In particular, the mortality and economic losses associated with disaster risks in lowand middle-income countries are an uptrend, with the average of economic losses from disasters reaching an

Correspondence: mizanbfbisri@stu.kobe-u.ac.jp

Department of International Cooperation Policy Studies, Graduate School of International Cooperation Studies, Kobe University, GSICS Building, 2-1

Rokkodai, Nada-ku, Kobe-shi, Hyogo-ken 657-8501, Japan average of US $\$ 250$ billion to US\$300 billion each year (UNISDR 2015).

These disasters have happened in the face of diminishing resources for aid relief, humanitarian operations, and reconstruction. For example, there has been a significant reduction in official development assistance from major donors for disaster relief and it is believed that this trend will continue even until the post-2015 period (Cahill 2012). Salvatore (2012) provides more evidence that over the past decade, international governments have spent about $\$ 90$ billion on humanitarian assistance, although the actual needs were far greater. He further claims that aid spending often covers no more than two thirds of aid needs. At the same time, inter-relationships between multiple humanitarian actors from global to local levels continue to search for optimum cooperation processes and coordination structures (Gillmann 2010; Taylor et al. 2012; Fredriksen 2012) within a complex network of polycentric disaster governance (Lassa 2015) and on how to improve performance on humanitarian aid delivery (Moore et al. 
2003; Beck 2006; Tomassini and Wassenhove 2009; Taylor et al. 2012). Therefore, research on networks of actors in a given disaster case and how it affects humanitarian aid operations will contribute to the discourse.

The topic of coordination and cooperation in managing contemporary disasters and other humanitarian emergencies is linked to a broader debate on the relative roles of the state, the private sector, and non-governmental organizations in ensuring collective security. According to Lakoff (2010), the main concern is how lines of responsibility among diverse organizations should be drawn, in terms of both jurisdictional responsibility and technical capacity. Thus, to manage disaster situations, what is in need are either new regulatory norms or new organizational forms, i.e., with the particular role of the government being to design a mechanism in doing so. Furthermore, Jasanoff (2010) also noted a similar notion: contemporary disaster risk and its response have escaped the control of technocratic managers and should be understood more broadly as a problem of democratic governance. Specifically, the ongoing discourse is whether coordination and cooperation during a disaster situation should be centralized or decentralized. Roberts (2010), based on the US Federal Emergency Management Agency, states that governing disaster response requires a networked form of government that links the federal, state, and local levels of the government and private organizations (including non-government organizations (NGOs)). Thus, even though these actors share common goals, they are not subject to direct command; hierarchy alone is a poor tool to respond to disaster. In his view, successful disaster response occurs not through command from above but through loose networks of formal organizations and informal professions that maintain broad agreement about shared goals and responsibilities. Lassa (2015) stated that the observed "tragedy of commons" following the Indian Ocean Tsunami of the 2004 shows the complexity of the network in the post-disaster governance.

In practice, the preceding discourse is evident with the establishment of the humanitarian clusters after the Indian Ocean Tsunami in 2004. The cluster approach is an effort for coordinating humanitarian actors by sector aimed at improving the effectiveness, predictability, and accountability of humanitarian response (Fredriksen 2012). It was launched in 2005 by the Inter-Agency Standing Committee (IASC). A cluster is a group of organizations in a specific sector of humanitarian response that works together to coordinate operational activities (IFRC 2012). It is also a formal humanitarian coordination forum for sectors of the response at the country level (Clarke and Campbell 2015). At the global level, it comprises 11 clusters: (1) camp coordination and management; (2) food security; (3) early recovery; (4) education; (5) emergency shelter; (6) health; (7) nutrition; (8) protection; (9) water, sanitation, and hygiene (WASH); (10) emergency telecommunications; and (11) logistics.
The arrangement of a cluster is applied at both the international level and at the country level in which the latter generally mirrors the global clusters. Indonesia is one of the countries which adopted the cluster approach. The IASC team in Indonesia and the Government of Indonesia produced a national contingency plan in early 2009, a few months before the earthquakes studied here (IASC 2009). However, depending on each country and the emergency itself, some clusters can be combined (IASC 2006) and that the clusters are activated when there is an international response to an emergency upon request of the host government (IFRC 2010).

In each cluster, the IASC has designated a lead agency, i.e., an agency responsible for providing leadership in the cluster which would be accountable to the UN Emergency Relief Coordinator (ERC) through the United Nations Office for Coordinating Humanitarian Affairs (UNOCHA). At the global level, the lead agency manages three areas: standards and policy setting, capacity building, and operational support. The cluster approach encourages the global cluster lead to be proactive in ensuring partners include national and local organizations. Meanwhile, the countrylevel clusters are tasked with coordinating actors in each sector in specific crisis responses and ensuring that standards for practice set by the global clusters are met during these responses (IASC 2006).

At the country level, national government ministries formally act as co-chairs in cluster meetings, sometimes even acting as cluster co-leads with the appointed lead agency (Fredriksen 2012). The extent to which government ministries participate as true partners in the clusters, however, varies greatly from country to country. In Indonesia, government ministries have been active participants in the cluster-based coordination of humanitarian responses to natural disasters within their territories (Fredriksen 2012). The existence of representatives from the government as co-leads in the cluster is also seen as a source of legitimacy. To this end, whether or not a lead agency in a cluster truly acts as the ultimate leader which governs all government/ non-government humanitarian actors is still perceived, by many, as debatable. Furthermore, in reality, even within the same country during the same disaster, cluster hubs can be set up in several locations and a lead agency may be appointed differently in each hub or administrative boundary.

Specific to the IASC clusters, Clarke and Campbell (2015) state that the term "coordination" inside the humanitarian sector often describes loosely a variety of different kinds of relationships and coined that in reality, there are three levels of coordination between complete independence and full merger during humanitarian operations, i.e., communication, alignment and collaboration. According to their research, humanitarian clusters generally fall in to the "alignment level," i.e., organizations retain a high 
degree of independence but may adjust their activities to create a more effective response on the basis of activities of other organizations. The research was able to showcase that generally, cluster members decided to join a coordinated response since the benefits (access to guidance and information, opportunities to build relationships and see the bigger picture, as well as increased legitimacy for activities) outweigh the cost (time, loss of autonomy, and competitive advantage). However, their concept of coordination levels will not be able to visualize the actual network of multiple organizations engaged in emergency response of a humanitarian crisis. In addition, their work is also limited to the observation of the cluster's work regarding joint strategy development and joint assessments and thus does not looked into actual relationship of cluster members in the implementation of emergency response activities.

Gillmann (2010), on the other hand, used insights from the Darfur Crisis and Indian Ocean Tsunami in 2004 and proposed four typologies for cooperation of humanitarian efforts, i.e., Loose Alliance, Orchestrated Alliance, Lead Partnership, and Lead Agency, whereas the illustration and brief description of each type can be seen in Fig. 1. Among this typology, Gillmann argues that a lead-agency network is the best pattern for inter-organizational cooperation at the time of a disaster, to best meet the standard performance of humanitarian operations. The proposition of the typology is very important and, as she herself suggests, needs to be tested in other cases. Even though her work also originates from network theory, her approach is fully qualitative and only incorporates global humanitarian actors and does not incorporate local actors, which in reality also participate in the humanitarian efforts.

Therefore, in this paper, the author would like to test the typology proposed by Gillmann (2010) using a larger dataset of actors. For testing, at least two comparable case studies are needed. Accordingly, this paper will comparatively study inter-organizational cooperation of emergency response in two earthquakes in Indonesia, i.e., the West Java Earthquake on 2 September 2009 and the West Sumatra Earthquake on 30 September 2009, and their impact on humanitarian aid delivery operations. Both earthquakes happened at nearly the same time, in the same country, and fall within the same emergency level based on the Indonesian IASC Contingency Plan (IASC 2009). In addition, both earthquakes in their occurrence serve as an early test to the newly established Indonesian Disaster Management system of Law 24/2007 and humanitarian clusters adopted by global humanitarian actors as defined by UN Resolution 46/182. The author agrees with DARA (2010) and Wilson (2010) that both earthquakes provide a stark comparison of response after natural disasters in the same country. The cases are expected to show the difference of network creation, given the different trajectories of political decision of the government in responding to each earthquake, particularly on perception of the strength of the state and decision to activate humanitarian clusters, which include that of international organization.

\section{Objectives and research questions}

In general, this paper aims to contribute to the theoretical discourse as well as practical queries in the subject of inter-organizational cooperation arrangement at the time of disaster and humanitarian crisis. The specific research goal is to comparatively investigate inter-organizational cooperation and its humanitarian operation performance during the emergency response of the West Java Earthquake 2009 and the West Sumatra Earthquake 2009. Accordingly, the research objectives include the following: (1) examine the practices of inter-organizational cooperation during the emergency response of both earthquakes; (2) model the networks of inter-organizational cooperation during the emergency response of both earthquakes and explore their characteristics, i.e., by using social network analysis (SNA) performed using UCINET version 6.532 (Borgatti et al. 2002) and categorized based on Gillmann's typology (Gillmann 2010); (3) identify and compare performance of humanitarian aid operations resulting from the given network of actors and its cooperation, i.e., by using some criteria conceptualized by Beck (2006); and (4) identify policy implications and their practical relevance to the humanitarian field, e.g., in the context of Indonesia, Southeast Asia, and international humanitarian system in general.

To meet the aforementioned objectives, the following research questions are addressed: (1) In what ways did

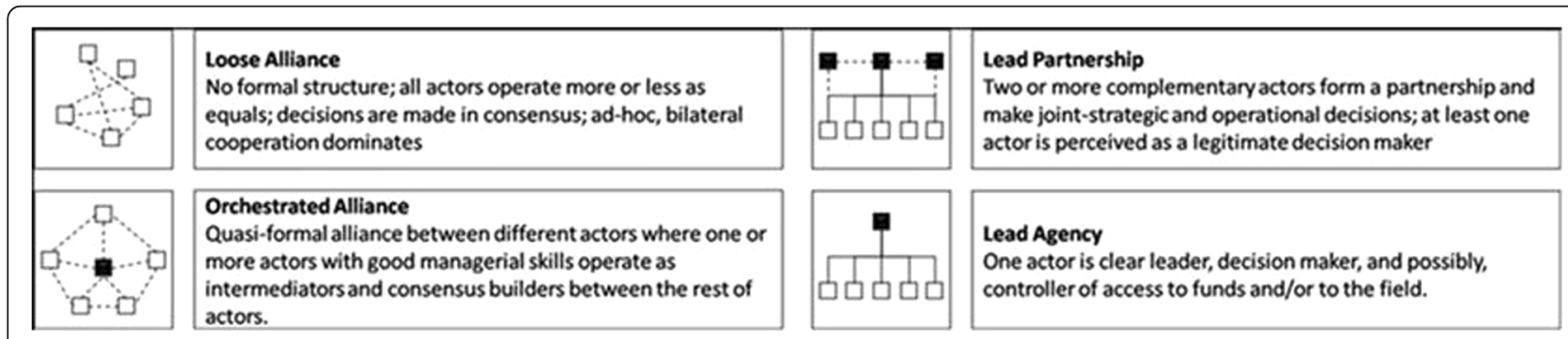

Fig. 1 Typology for inter-agency coordination of humanitarian efforts at the time of disaster (Gillmann, 2010) 
inter-organizational cooperation function and create networks during the emergency response of both earthquakes? (2) What were the characteristics of cooperation in humanitarian operations within the networks during the emergency response of both earthquakes? (3) Which type of network performed better in the emergency response of both earthquakes?

\section{Methodology: social network analysis and data collection method}

This research includes both quantitative and qualitative approaches. SNA has been chosen as the main approach in this study due to its ability to represent the structure of relations between actors and to analyze a large number of relations within a network (Prell 2012). In short, SNA is the study of the structural relationships among interacting network members (individual, organizations, etc.) and of how those relationships produce varying effects (Varda et al. 2009).

In regard to the utilization of SNA in disaster and humanitarian studies, a variety of research has been conducted. Some research applies SNA for analyzing the individual level of network in disasters, while others are more concerned with organizational issues. Some individual-level research of SNA may give explanations of who is at risk, who has more capacity to recover (Haines et al. 1996), and how individual strategies recover after a disaster (Hulbert et al. 2005). Other research focuses on the organizational level of SNA to analyze inter-organizational cooperation related to a disaster. For example, in organizational-level research on developed countries, Kapucu et al. (2010) give a broader view of aid and emergency response following Hurricane Katrina and by employing full quantitative SNA techniques, they successfully show that further investment in the State Government is needed because it proved to be the key actor. Other studies were able to explain factors which decide organizations' motivations to create, maintain, dissolve, and reconstitute the inter-organizational links during Hurricane Katrina by comparing results from manual and computed social network analysis (Varda et al. 2009). However, both studies have made little contribution to the greater discourse on how to improve global cooperation for humanitarian efforts at the time of disaster, since they primarily concentrate on the case from a developed country, in which there is not much cooperation among international and local actors. Alternatively, another example came from the SNA model of inter-organizational cooperation during the Great East Japan Earthquake and Tsunami 2011 (Bisri 2016). Using the Japan case, Bisri (2016) was able to showcase that multiple actors engage during the emergency response at the time of the 2011 tsunami, ranging from traditional and nontraditional humanitarian actors. However, the effect of the network to the humanitarian operation performance was not within the scope of this paper.
Few studies used SNA to analyze disaster in developing and least-developed countries. Among them, Moore et al. (2003) examine the role of network centrality in humanitarian operations following the 2003 Mozambique Flood in which over 49 countries and 30 international NGOs were involved in the relief effort. They tried to analyze whether organizations with the potential to connect with a number of other organizations were involved in higher impact projects. As a result, they found that international NGOs were highly central to the network of collaborators and that centrality measurement result did affect the number of the project's beneficiaries. On the other hand, Kumar (2011) analyzed inter-organizational networks during the emergency response of the 2007 Peru Earthquake. By analyzing the network of 300 organizations using SNA, he argues that there was a pattern in the collaboration behavior of organizations involved in the earthquake relief effort, i.e., large international organizations played a more central role in the overall relief effort. In addition, he compares the behavior of collaborations at various humanitarian clusters as well as between three municipalities affected.

In Indonesian context, Lassa (2010) uses SNA to identify the relation among institutional features in disaster risk management of Indonesia. He maps out which regulation is the most referred to by the government and which actor is the most central in disaster risk management in Indonesia. Furthermore, by analyzing the polycentric governance using SNA of the post-disaster stage of the Indian Ocean Tsunami 2004, he shows important features of the network of disaster actors, i.e., the degrees of separation on the postdisaster network reflect the "small world" realities, existence of loops in the network that reflect the tendency of some actors not to cooperate, and importance of certain hubs in the network and the humanitarian cluster, while other actors make scattered single principalclient links (Lassa 2015).

In this research, SNA is being performed using the UCINET version 6.532 (Borgatti et al. 2002) to produce network graphs of both cases and analyzes the complete network structure by performing egocentric measurements on degree centrality and betweenness centrality, i.e., which are common disaster research (Moore et al. 2003; Varda et al. 2009; Kapucu et al. 2010; Kumar 2011; Bisri 2016). Degree centrality is a measurement of an actor's level of involvement or activity in the network, and it calculates the number of immediate contacts an actor has in a network (Prell 2012, pp. 96-103). Betweenness centrality is a measurement of to what extent an actor is located in the direct path of exchange between two other actors in the network (Wasserman and Faust 1994). It looks at how often an actor rests between two other actors, i.e., calculates how many times an actor sits on the geodesic (the shortest path) linking two other actors together. The degree centrality and 
betweenness centrality are the two common measurements used as a proxy of an actor's relative position in the coordination structure. In addition, sociometric measurements were also performed, i.e., density and clique identification. Density refers to the proportion of ties in a network that are actually present, and it counts how many actual ties exist in a network and expresses this number as a proportion of the potential ties that could exist in the network (Prell 2012, pp. 166-167). Lastly, a clique is an informal grouping of actors in the network which indicates the strong cohesiveness in the subgroup; it refers to subgroups of actors consisting of mutual ties (Prell 2012, p. 155). In a disaster situation, a clique is subsets of organizations that develop recurring patterns of interaction (Scott 2000).

In this research, the "nodes" represented in the SNA model are organizations performing emergency response activities, which range from national and local government units, international NGO, local NGO, and agencies of the UN, while the "ties" that link two nodes represent joint delivery of emergency response activities, i.e., combine all possible cooperation from financial support, human resource mobilization, and in-kind contribution. All the measurements were done in "valued" and "directed" mode, meaning that frequency and direction of relationship among actors are detected and become sensitive to each SNA measurement. In the model, the valued network gives weight to each tie; thus, if a tie appears to be thicker, it means more than one cooperation (joint implementation of emergency response) were being done by those connected two organizations.

Given the result of SNA, the model of networks from both cases will be contrasted with the typology suggested by Gillmann (2010). To bridge these two approaches, Gillmann's typology of networks (i.e., loose alliance, orchestrated alliance, lead partnership, and lead agency) is used so that the result of egocentric measurements through SNA (degree centrality, betweenness, closeness, and eigenvector centrality) of networks in both cases, drawn in principalcomponent network mode, will fall into one category of the typology. The use of principal-component is essential to bridge the visualization of SNA with the typology of Gillmann, as the novelty of this paper.

To further analyze how the inter-organizational cooperation network affects humanitarian aid operation performance, several criteria provided by Beck (2006) will be used. There are seven criteria in evaluating humanitarian action: relevance or appropriateness, connectedness, coherence, coverage, efficiency, effectiveness, and impact. It is positioned as the continuation of DAC criteria in evaluating humanitarian action, whereas Beck (2006) adds another three criteria to merge with the original five criteria and thus the seven aforementioned criteria. Given the nature of this research, which is a more "system-wide" analysis, the most appropriate criteria to assess humanitarian aid operations in both West Java and West Sumatra Earthquakes 2009 are coherence, coverage, and connectedness.

According to Beck (2006), coherence refers to the need to assess humanitarian policies and actions taken by actors, to ensure that there is consistency and that of overlap in actions was avoided. Thus, there will be two indicators in measuring coherence, i.e., (1) existence and timeliness of joint-assessment and/or joint-humanitarian action plan and (2) qualitative performance coordination mechanism and information sharing, while the criterion of coverage concerns on the need to reach major population groups facing life-threatening suffering wherever they are. Thus, indicators of coverage are the total and percentage of beneficiaries, geographical, and timeliness distribution of humanitarian aid in clusters. Connectedness refers to the need to ensure that activities of a short-term emergency nature are carried out in a context that takes longer term and interconnected problems into account. Thus, existence and timeliness of the Damage and Loss Assessment (DALA), Human Recovery Need Assessment (HRNA), and Post-Disaster Need Assessment (PDNA) documents, as well as the continuation of organizational presence from emergency response to the recovery phase, will be used as indicators.

A desk study has been completed, which gathered information regarding emergency response activities in both earthquakes from Situation Reports published by BNPB (National Disaster Management Agency), Indonesian Ministry of Health, and United Nations Office for Coordination of Humanitarian Affairs (UNOCHA), as well as the 3W Matrix (who is doing what and where) compiled by the humanitarian partners. In creating the dataset for SNA on both cases, information gathered from the desk study is reorganized into a "database of emergency response activities." In the database, each activity contains the following fields: organization name and type, location of activity, type of activity, sector in which the project is classified (e.g., shelter), organization(s) responsible for the activity, description, progress of activity, classification of financier/ executor, and beneficiaries. Given the information compiled in the database, a relational matrix (proxy of cooperation) of emergency response is developed. Activities included in the dataset are those implemented during the emergency response period, by two or more organizations. An activity that is said to be implemented by a single organization and/or did not clearly state its implementing partner will not be included in the dataset of input to the SNA. The sample of emergency response activities is classified into 12 groups, in relation to humanitarian cluster arrangement, as follows: food distribution (FD); non-food item distribution (NFI); health services (HS); disaster impact rapid assessment (RA); search and rescue (SAR); coordination and communication (CC); cash support and donation $(\mathrm{CD})$; education in emergency time (Edu); water, 
sanitation, and hygiene (WASH) promotion; shelter (Shelter); logistics (LOG); and others.

In the West Java case, the official emergency period was dated from 2 to 16 September 2009. However, in reality, the response was performed for the whole of September; thus, all emergency response activities until 30 September 2009 were included in the dataset, i.e., accounted for taken into consideration. On the other hand, the official emergency response for the West Sumatra Earthquake 2009 was defined for 1 month. Therefore, activities dated from 30 September until 30 October 2009 were included in the dataset, i.e., accounted for 431 sample of emergency response activities.

The second method of data collection is through semistructured interviews to key actors identified from the dataset and first iteration of the SNA modeling, i.e., can be said as key organizations. For each organization, author interviewed resource persons who came from ministries of the central government (e.g., National Disaster Management Agency-BNPB), agencies of West Java and West Sumatra Provincial Governments (e.g., Local Disaster Management Office-BPBD), agencies at local governments in affected areas, agencies of the United Nations (e.g., UNOCHA) international and local NGOs, and university/research institutions. Resource persons interviewed are those who are directly involved as responder in the emergency response of the earthquake or knowledgeable of the case. During the interviews, confirmation to the initial findings of preliminary SNA results was addressed to resource persons. In addition, they were asked about the questions related to the humanitarian operation performance (coherence, coverage, and connectedness) of the earthquakes.

\section{The West Java and West Sumatra Earthquakes 2009, aftermath, and response}

The West Java Earthquake 2009 occurred on Wednesday, September 2, at 14:55 local time with a magnitude 7.3 on the Richter scale and epicenter located $142 \mathrm{~km}$ southwest of Tasikmalaya City, at a depth of $30 \mathrm{~km}$ below sea level. This earthquake occurred due to the subduction of plates between the Indo-Australian plate and the Eurasian plate, in the southern part of Java Island. Fifteen municipalities were affected, with 81 people dead, 1287 people seriously injured, and 50,964 households or 194,805 people displaced (Bappenas 2009).

The first official statement was delivered by the West Java Governor at 22:30 on the same day in the form of West Java Governor Decree SK 360/kep.1260-Hukham/2009 regarding Emergency Response Status. It was immediately followed by the formation of Satkorlak West Java (Coordinating Task Force for Disaster Response), and the first emergency response team was dispatched by the provincial government. ${ }^{1}$ The response phase was set for a 2-week period, and the priorities were as follows: (1) organizing disaster relief, (2) conducting a study and rapid assessment for disaster impact and victim search and rescue, (3) conducting rescue and evacuation, (4) fulfillment of basic needs, (5) protection of vulnerable groups, and (6) restoration of immediate infrastructure and facilities. ${ }^{2}$ Similarly, activation of emergency response activities by agencies at the municipality government level also took place. The central government, BNPB in particular, supported the decision taken by its provincial counterpart, and it sent an assessment and quick response team to West Java and connected them with the other line ministries and agencies, such as the Ministry of Health, army, and police. On 3 September 2009, President Yudhoyono, Minister of Health, Minister of Social Affairs, and Head of BNPB, visited the affected areas. $^{3}$

Meanwhile, UN agencies held a coordination meeting and sent their own joint-assessment team by 3 September 2009, 05:00 in the morning. ${ }^{4}$ The purpose was to determine whether they would intervene, i.e., since at that time, there was no formal contact made with the government. ${ }^{5}$ In parallel, some local and international NGOs, independently or jointly, started to enter the field and perform immediate rescue activities and disaster-impact assessments. Coordination between government-led humanitarian efforts and those of $\mathrm{UN}$ agencies were made later on 5 September 2009, where BNPB and UNOCHA facilitated meetings to update the joint assessments. ${ }^{6}$

Within the first $72 \mathrm{~h}$, the government claimed that the local and national governments had enough resources to respond to the crisis. President Yudhoyono even stated that international assistance was not required and the government remained capable of handling the emergency response given the approximately US $\$ 530,000$ financial support from the central government. ${ }^{7}$ In the subsequent process, the government insisted, under assumption of West Java's capacity and its proximity to Jakarta, that the emergency response could be handled by joint efforts from central, provincial, and local governments, in addition to national and local NGOs on the field. The Indonesian government was keen to demonstrate that 5 years after the Aceh Tsunami, they could respond to a disaster efficiently and effectively (DARA 2010). The earthquake was perceived as a time to show the international community that Indonesia could single-handedly manage the emergency response of a medium-large disaster. ${ }^{8}$

However, the shortage of manpower and organizational capacity in some sectors resulted in slow progress in the emergency response. In terms of organizational capacity, the absence of BPBD (Provincial Disaster Management Agency) in West Java could be the factor, which was actually mandated by Law 24/2007 on Disaster Management. Another factor that could be overlooked by the government was that the emergency response periods coincided with the holiday season of Eid al-Fitr, leaving the capacity 
to respond lower than initial expectations. ${ }^{9}$ In the health and social sectors, the shortage of manpower was compensated through the network of national and local health agencies with numerous universities which have medical faculty. Many of the doctors and nurses volunteered during the emergency response. In addition, the Ministry of Health and Ministry of Social Affairs also has their own national volunteer networks, which were mobilized from neighboring regions. In other sectors, gaps were identified for rapid assessment, water sanitation, and temporary shelter provision, given the lack of skills and manpower from local governments and local NGOs. Therefore, after 1 week, BNPB made a statement that in-country assistance, whether from national or international organizations, was welcomed and would be coordinated under the leadership of BNPB and Satkorlak West Java. ${ }^{10}$

Given the change in the BNPB statement, two UNOCHA staff members were deployed to Satkorlak West Java to help the coordination with humanitarian organizations in the affected areas. Thus, it was agreed that four clusters would be activated through coordination with UNOCHA and Satkorlak West Java, i.e., education and water-sanitation clusters were led by UNICEF, the shelter cluster was led by the International Federation of Red Cross (IFRC), and early recovery (including disaster impact assessment) was led by the United Nations Development Program (UNDP). In addition, UNOCHA routinely convened UN-NGO-Donor Coordination meetings for emergency response of the earthquake. The other humanitarian sectors and health services as well as search and rescue remained under the complete leadership of the government with support from local/national NGOs. To complement these changes, the provincial government issued two additional new decrees, i.e., the formation of the Emergency Response Team for West Java Earthquake (No. 360.05/Kep. 1263-Hukham/2009) and the Allocation of Emergency Response Funds (No.900/Kep 1265-Keu/2009).

In total, during the emergency response periods of the West Java Earthquake 2009, there were 343 activities identified. Distribution of activities can be seen below. The delivery of NFI (e.g., blanket, tent, mats) dominated the emergency response (64 activities), followed by health services and cash donation (each 51 activities), see Fig. 2.

The West Sumatra Earthquake 2009 occurred on 30 September 2009, 17:16 local time, and measured 7.6 on the Richter scale with the epicenter located $45 \mathrm{~km}$ southwest of Padang City. As an aftermath, the earthquake caused 1117 deaths and 2902 injuries (BNPB 2009). In addition, there were 250,000 families (around $1,250,000$ people or $25 \%$ from total West Sumatra population) being internally displaced and affected by the earthquake. In total, there were 249,653 houses damaged, i.e., 114,797 homes severely damaged, 67,198 moderately damaged, and another 67,658 lightly damaged (BNPB 2009).

Since the West Sumatra Earthquake 2009 occurred less than a month after the one in West Java, it placed a second wave of demands on the Indonesian disaster management authorities. Given this situation, after a high-level ministerial meeting, BNPB announced that emergency response to the earthquake and relief provisions would take place for 2 months, ${ }^{11}$ i.e., although it was later reduced to 1 month given the performance of emergency response activities from both local and international organizations. ${ }^{12}$ Along with the decision from BNPB, President Yudhoyono announced that the Government of Indonesia welcomed international assistance but needed to be coordinated through the government. ${ }^{13}$

In the first $24 \mathrm{~h}$, different from the approach in West Java, the Governor of West Sumatra, Satkorlak West Sumatra, and under approval from BNPB, invited the UNOCHA to become their counterpart in managing coordination and cooperation for humanitarian aid delivery in both emergency response and early recovery ${ }^{14}$; even the governor provided an office for UNOCHA in his residence (DARA 2010). As an immediate response, a joint mission from the $\mathrm{UN}$, led by UNOCHA and comprised of officers from FAO, UNDP, UNFPA, UNICEF, and WHO, was deployed to Padang City within the first $18 \mathrm{~h}$. Later on, the UN mission was empowered by the arrival of the UNDAC team (UN Disaster Assessment and Coordination). Also, in the evening of the quake day, BNPB coordinated deployment of its own personnel and other national ministries; they reached West Sumatra in the dawn of 1 October 2009 and were perceived timely by the provincial government and its city counterpart. ${ }^{15}$ On the other hand, some international NGOs independently also started to send their teams to West Sumatra, in particular those affiliated with the ECB Consortium, which in this earthquake was led by Mercy Corps. It seems that local authorities did not want to repeat the same mistakes made in West Java.

Although it was not fully operational within the first week, less than $48 \mathrm{~h}$ after the earthquake, it was agreed that the humanitarian cluster approach would be activated. ${ }^{16}$ There were ten humanitarian clusters: (1) agriculture with FAO and UNDP as lead agencies; (2) coordination and safety and early recovery with UNDP and Bappeda West Sumatra as lead agencies; (3) education with UNICEF, Save the Children (STC), and Education Agency of West Sumatra as lead agencies; (4) food and nutrition with WFP and UNICEF as lead agencies; (5) health with WHO and Health Agency of West Sumatra as lead agencies; (6) logistic and telecommunications with WFP as lead agency; (7) protection with UNICEF, UNFPA, and Social Agency of West Sumatra as lead agencies; (8) shelter with IFRC as lead agency; (9) water, sanitation, and hygiene (WASH) with UNICEF as lead agency; and (10) emergency telecommunications with WFP 


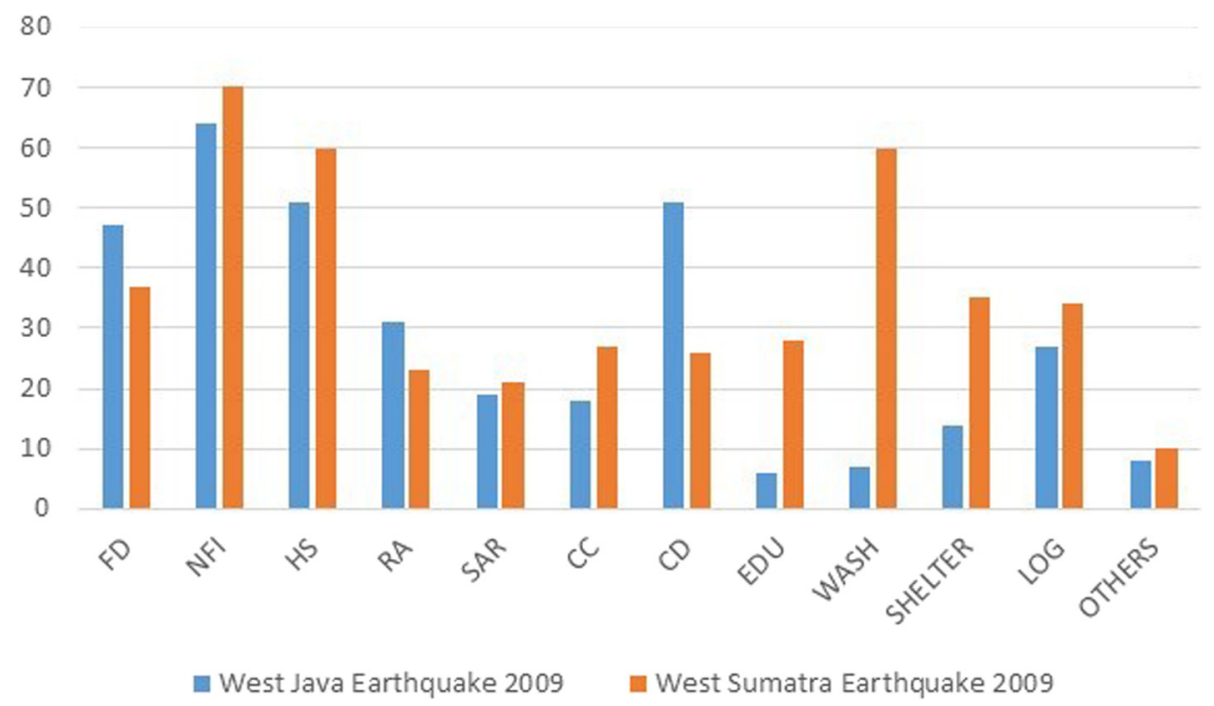

Fig. 2 Number of emergency response activities in both earthquakes (Source: author's calculation from various situation reports)

as lead agency. Members of each cluster were comprised of both local and international actors.

During emergency response periods in West Sumatra, 431 sample activities were identified, which took place from 30 September to 30 October 2009. As can be seen from Fig. 2, activities related to NFI distribution to disaster victims and refugees ranked the highest (70 activities), followed by health service and WASH (each 60 activities). Variations of activities not categorized in the preceding 11 groups include debris removal activity, a cash-for-work program, distribution of disaster-risk-reduction booklets, and economic recovery programs for small-medium enterprises.

\section{Network of inter-organizational cooperation in West Java and West Sumatra}

As can be seen in Fig. 3, in the 2009 West Java Earthquake, there were 192 organizations involved in emergency response, and most organizations were national/local NGO (50) and local government agencies (45). There were also 22 international NGOs identified, of which some of them were already in West Java due to their operations in the recovery of the 2006 Pangandaran Tsunami. Also, there were 21 universities involved, most of which were represented by their medical faculty in the health cluster. There were 18 agencies from provincial governments and 10 agencies/ministries from central governments. In addition, 16 private companies contributed by giving cash or in-kind assistance. In terms of UN agency deployment, there were eight, and only two foreign government agencies involved. On the other hand, in West Sumatra, there were 223 organizations involved. Record showed involvement of 63 international NGOs (28\%) and 40 local government agencies $(18 \%)$. The number of foreign governments which provided assistance was also quite high, accounting for 35 agencies (16\%). In terms of national/local NGOs, there were 29 organizations $(13 \%)$. On the other hand, 17 agencies and ministries of the central government also intervened directly (8\%), and so did 18 agencies of the provincial government $(8 \%)$. Lastly, there were 12 agencies of the UN (5\%), three universities (only $1 \%$ ), and six private companies (only $3 \%$ ) involved.

Based on the data of actors and emergency response activities, network analysis was performed. The network in West Java comprises 192 nodes (identified actors) and 729 ties which resulted from 343 identified activities, while the network in West Sumatra comprises 223 nodes and 865 ties resulted from 431 identified activities. Furthermore, calculation on degree and betweenness centrality of all actors in both networks was performed, and the result of the top- 15 actors with the highest centrality can be found in Fig. 4.

In comparing networks created in both earthquakes to fit in Gillmann's typology, the principal-component-mode visualization was performed, based on the value of degree and betweenness centrality above. This step visualizes the result of degree and betweenness centrality measurements in a graph and clarifies better which organizations served as leader(s) or as follower(s) in the network. As can be seen in Fig. 5, the network in West Java fits the leadagency type of network in Gillmann's typology, with one provincial government body ranked significantly as the network's leader having clear authority as a decision maker and controlled access to the field, which was also supported closely by BNPB, the central government. At the same time, several organizations leading four clusters in West Java had a distant position with the lead agency, i.e., PMI (Indonesian Red Cross), IFRC, UNICEF, Ministry of Health (Kemenkes), and Health Agency (Dinkes) of 


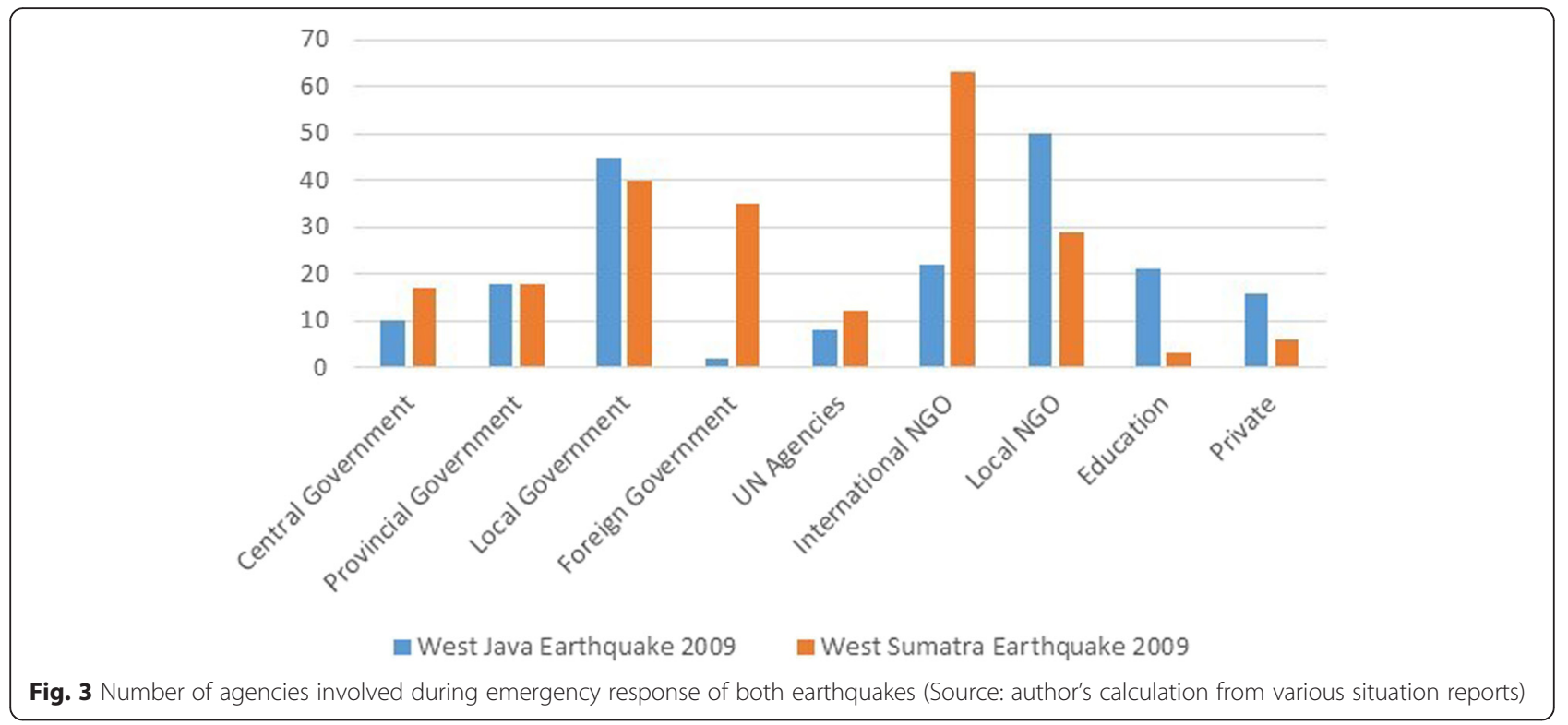

West Java. Based on degree centrality measurement, as can be seen in Fig. 4, the network was very centralized and linked to Satkorlak West Java with its normalized degree centrality 6.702. As a national agency, BNPB thus ranked second in terms of degree centrality, which mainly supported and supervised Satkorlak West Java, since the province did not have their own BPBD. Dinkes West Java also ranked third with high degree centrality since the agency mostly bridged the Kemenkes and health agencies at the municipality level. Afterwards, UNOCHA ranked fifth in terms of centrality due to its network with INGOs and local NGOs and the late introduction of cluster arrangement. There are two national NGOs which scored high in terms of degree centrality, i.e., PMI, ranked fifth, and PKPU, ranked seventh. PMI has pre-established branches at provincial and local levels, while PKPU was involved in several humanitarian clusters at one time.

While viewed from the principal-component network mode, the network of actors in West Sumatra fits the leadpartnership type. As can be seen from Fig. 5, Satkorlak West Sumatra, UNOCHA, UNICEF, IOM, IFRC, BNPB, STC, WFP, and UNDP are identified as principals of the network. Those organizations were the focal points of the network, BPBD West Sumatra, BNPB, and UNOCHA, with the remaining organizations all humanitarian cluster lead agencies. It is seeming that the "cluster approach" did function in orchestrating emergency response during the West Sumatra Earthquake 2009. In addition to UNOCHA, BNPB, and Satkorlak West Sumatra, among the top-15 organizations with the highest degree centrality, almost all

\begin{tabular}{|c|c|c|c|c|c|c|c|c|c|c|c|c|c|c|c|}
\hline \multirow{2}{*}{\multicolumn{4}{|c|}{ WEST JAVA EARTHQUAKE 2009}} & \multicolumn{12}{|c|}{ WEST SUMATRA EARTHQUAKE 2009} \\
\hline & & & DEGREE CENTRALITY & \multicolumn{4}{|c|}{ BETWEENESS CENTRALITY } & \multicolumn{4}{|c|}{ DEGREE CENTRALITY } & \multicolumn{4}{|c|}{ BETWEENESS CENTRALITY } \\
\hline Rank & Organization & Degree & $\begin{array}{c}\text { Normalized } \\
\text { Degree }\end{array}$ & Rank & Organization & Betweeness & $\begin{array}{l}\text { Normalized } \\
\text { Betweeness }\end{array}$ & Rank & Organization & Degree & $\begin{array}{c}\text { Normalized } \\
\text { Degree }\end{array}$ & Rank & Organization & Betweeness & $\begin{array}{l}\text { Normalized } \\
\text { Betweeness }\end{array}$ \\
\hline 1 & $\begin{array}{c}\text { Satkorlak West } \\
\text { Java }\end{array}$ & 128.000 & 6.702 & 1 & $\begin{array}{c}\text { Satkorlak West } \\
\text { Java }\end{array}$ & 25327.910 & 69.793 & 1 & UN OCHA & 64.000 & 4.762 & 1 & $10 \mathrm{M}$ & 4254.489 & 11.601 \\
\hline 2 & BNPB & 52.000 & 2.723 & 2 & BPBD Cianjur & 4540.551 & 12.512 & 2 & UNICEF & 53.000 & 3.943 & 2 & IFRC & 3091.425 & 8.430 \\
\hline 3 & Dinkes West Java & 45.000 & 2.356 & 3 & Dinkes West Java & 2126.770 & 5.860 & 3 & IOM & 40.000 & 2.976 & 3 & BNPB & 2953.556 & 8.054 \\
\hline 4 & UN OCHA & 42.000 & 2.199 & 4 & BNPB & 1600.035 & 4.409 & 4 & BNPB & 39.000 & 2.902 & 4 & $\begin{array}{l}\text { Satkorlak West } \\
\text { Sumatra }\end{array}$ & 2851.284 & 7.775 \\
\hline 5 & PMI & 33.000 & 1.728 & 5 & PMI & 1453.605 & 4.006 & 5 & $\begin{array}{l}\text { Satkorlak West } \\
\text { Sumatra }\end{array}$ & 34.000 & 2.530 & 5 & UNICEF & 2806.304 & 7.652 \\
\hline 5 & Kemenkes & 33.000 & 1.728 & 6 & Oxfam & 834.654 & 2.300 & 5 & IFRC & 34.000 & 2.530 & 6 & шно & 2093.680 & 5.709 \\
\hline 7 & 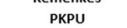 & 26.000 & 1.361 & 7 & Ітв & 824.974 & 2.273 & 7 & STC & 33.000 & 2.455 & 7 & UN OCHA & 1921.920 & 4.968 \\
\hline 8 & UNICEF & 23.000 & 1.204 & 8 & UNICEF & 774.560 & 2.134 & 8 & UNDP & 27.000 & 2.009 & 8 & Kemenkes & 1758.225 & 4.794 \\
\hline 9 & BPBD Cianjur & 21.000 & 1.099 & 9 & Disdik West Java & 654.177 & 1.803 & 8 & WFP & 27.000 & 2.009 & 9 & STC & 1681.196 & 4.584 \\
\hline \multirow[t]{2}{*}{10} & wvi & 17.000 & 0.890 & 10 & Jabar Peduli & 616.871 & 1.700 & 10 & $\begin{array}{l}\text { Bappeda West } \\
\text { Sumatra }\end{array}$ & 25.000 & 1.860 & 10 & UNDP & 1489.933 & 4.063 \\
\hline & YTBI & 17.000 & 0.890 & 11 & UN OCHA & 603.093 & 1.662 & 11 & UNFPA & 22.000 & 1.637 & 11 & PMI & 936.380 & 2.553 \\
\hline 12 & Oxfam & 16.000 & $\begin{array}{l}0.838 \\
0\end{array}$ & 12 & PKPU & 593.328 & $\begin{array}{l}1.6025 \\
1.635\end{array}$ & 12 & WHO & 21.000 & 1.563 & 12 & CRS & 772.258 & 2.106 \\
\hline 13 & TNI & 14.000 & 0.733 & 13 & Kemenkes & 410.452 & 1.131 & 13 & Kemenkes & 20.000 & 1.488 & 13 & FAO & 710.395 & 1.937 \\
\hline 14 & WFP & 13.000 & 0.681 & 14 & ASB & 362.113 & 0.998 & 14 & SIDA & 19.000 & 1.414 & 14 & Mercy Corps & 659.186 & 1.798 \\
\hline $\begin{array}{l}14 \\
15\end{array}$ & CRS & 12.000 & 0.0628 & $\begin{array}{l}14 \\
15\end{array}$ & $\begin{array}{l}\text { Satkorlak } \\
\text { Tasikmalaya }\end{array}$ & 358.563 & 0.988 & $\begin{array}{l}14 \\
15\end{array}$ & FAO & $\begin{array}{l}19.000 \\
18.000\end{array}$ & $\begin{array}{l}1.414 \\
1.339\end{array}$ & $\begin{array}{l}14 \\
15\end{array}$ & $\begin{array}{l}\text { Bappeda West } \\
\text { Sumatra }\end{array}$ & $\begin{array}{l}648.318 \\
\end{array}$ & 1.768 \\
\hline 15 & Hope & 12.000 & 0.628 & & & & & 15 & Bappenas & 18.000 & 1.339 & & & & \\
\hline 15 & Basarnas & 12.000 & 0.628 & & & & & & & & & & & & \\
\hline
\end{tabular}

Fig. 4 Result of degree centrality and betweenness centrality measurements (Source: author's analysis) 


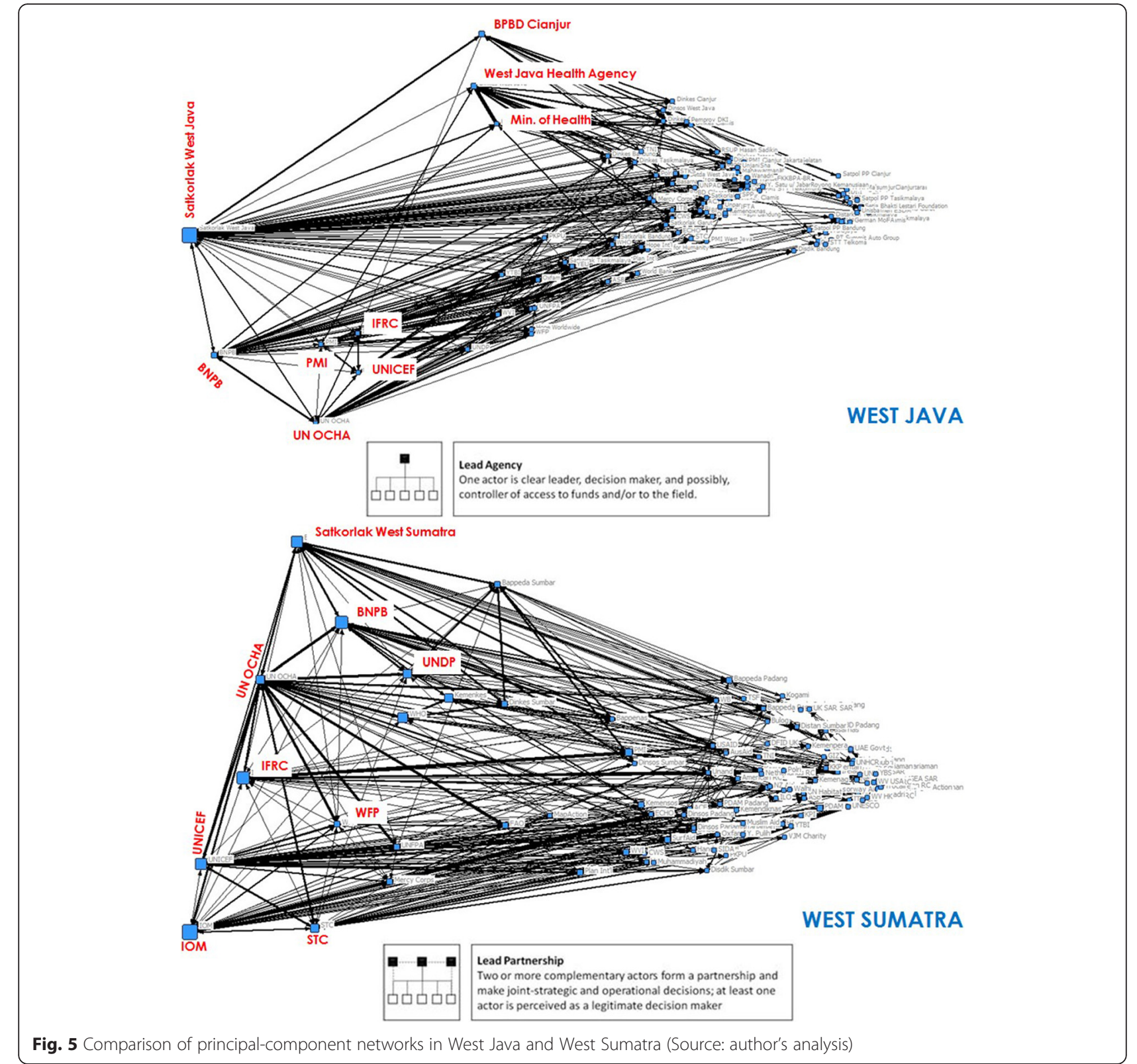

of them are the lead agency in each cluster. As the betweenness measurement reveals, organizations which play an important role in bridging other humanitarian actors ranked within the top ten. Most notably is IOM, which provided ground-transportation support for all organizations to deliver food, non-food items, and any other disaster relief aid to the affected areas. In the process, IOM later joined WFP to share the leading role in the logistic cluster. It was then followed by UNICEF, which bridged many members in education, food and nutrition, protection, and WASH clusters. Specifically, in the health cluster, the WHO also played an instrumental role in bridging international NGOs and local organizations through the Ministry of Health and Health Agency of
West Sumatra and thus ranked third in terms of betweenness centrality. As for IFRC, it had an instrumental role in bridging PMI with other Red Cross teams.

As a whole, the network density in West Java is 5.005 with 37 inter-organizational cliques detected, while in West Sumatra, the network density is 5.259 with 40 inter-organizational cliques detected. Clique analysis was completed with a minimum set size of four organizations, performed in directed measurement. Although the number of cliques is somewhat similar, the membership characteristic shows some differences. In the West Java case, out of 37 cliques identified, 10 of them purely consist of national-local organizations. Furthermore, 8 out of those 10 cliques are related to emergency response in 
the health cluster, which as described in the "The West Java and West Sumatra Earthquakes 2009, aftermath, and response" section initially did not invite activation of the health cluster under international humanitarian partner. The remaining 27 cliques are characterized as having a combination of at least national government agencies (e.g., BNPB, Basarnas, Indonesian Army, or Ministry of Health), at least one agency of the UN or international $\mathrm{NGO}$, and at least one agency of the West Java provincial government or national NGO. On the other hand, in the case of West Sumatra, only two cliques that purely consist of national-local agencies, i.e., a clique of BNPB, West Sumatra Province, Indonesian Police, and Indonesian Army, as well as a clique of the Ministry of Education, West Sumatra Education Agency, Bandung Institute of Technology, and Andalas University. The rest of the 38 cliques are a combination of international and national/ local organizations, with at least one out of the two cluster lead identified in the clique.

It should be noted that although both provinces have a similar level of organizational capacity, a different approach was taken in terms of how to orchestrate coordination and cooperation of emergency response and the statement of welcoming international assistance. By saying organizational capacity, it mainly refers to the fact that by September 2009, both provincial governments had not formed their BPBD and at the municipality level, their BPBDs were neither nonexistence nor still infant. In West Java, BNPB supported centralization of coordination to Satkorlak West Java and initially neither requested for international assistance nor encouraged activation of the humanitarian cluster system, while in West Sumatra, from the very beginning, the provincial government and BNPB welcomed international assistance and instantly agreed on activating the humanitarian cluster system. Consequently, Satkorlak West Sumatra, under supervision from BNPB, partnered with UNOCHA and other humanitarian clusters lead agencies.

\section{Humanitarian aid operation performance in West Java and West Sumatra}

Humanitarian operations in West Sumatra performed better in all criteria of coherence, coverage, and connectedness compared to West Java. As noted by Pranoto (2011), the UNDAC team praised Indonesia's capability in managing evacuation stages during emergency response in West Sumatra. While commenting on response in West Java, UNOCHA (2009) and DARA (2010) called the West Java Earthquake 2009 as a "forgotten disaster." In terms of coherence, West Sumatra's network was more cohesive, as indicated from the calculated network density (5.259) and number of cliques found (37). All nine humanitarian clusters were activated faster, within $48 \mathrm{~h}$, and legitimate, whereas humanitarian clusters were clearly being led by government agencies and UN agencies/INGOs, as in contrast with the four clusters activation 1 week after the earthquake with unclear appointments of government agencies to become counterpart of the cluster's lead agency in West Java. There were also more joint assessments identified, as opposed to the many uncoordinated assessments with delay in the official assessment found in West Java. Humanitarian aid operation in West Sumatra is also more coherent with the existence of the West Sumatra Earthquake 2009 Humanitarian Response Plan, whereas no similar document existed in West Java. These situations are indeed affected greatly by the initial statement of the government in responding to both earthquakes. In West Java, as mentioned by Wilson (2010), many NGOs felt confused and hesitant to intervene. While in West Sumatra, many actors appreciated the coordination of the humanitarian operations.

Humanitarian operations in West Sumatra also performed better from coverage criterion. During the first $72 \mathrm{~h}$ until the end of the first week, SAR activities in West Java ended with inadequate manpower to continue the remaining relief activities, while such a situation was not found in West Sumatra since, at the same period, international SAR teams already arrived and provided additional manpower. In West Sumatra, the emergency response was finished earlier than scheduled, shortened from 2 to 1 month, given the fast distribution of aid, while in West Java, it was extended from 2 weeks to 1 month. The time when external emergency relief started and the time needed until it reached beneficiaries were also faster than those in West Java (BNPB 2009), i.e., 4 to 7 days in West Sumatra and 7 to 9 days in West Java. Based on DARA's calculation (2010), 90 \% of needs in West Sumatra were actually being met even with only $37 \%$ fulfillment of the budget in the West Sumatra Humanitarian Response Plan, as opposed to only $60 \%$ in West Java. Based on the author's calculation, on average, $85 \%$ from total IDPs in West Sumatra covered or gained benefit from emergency provisions, while in West Java, only around $60 \%$. However, in terms of percent beneficiaries receiving health services and food aid in both West Java and West Sumatra, on average, $80 \%$ of the total affected people in each municipality did receive benefit.

Lastly, in terms of connectedness, humanitarian operations in West Sumatra also performed better. First, all DALA, HRNA, and PDNA documents which needed to ensure orchestrated emergency response and transition to recovery were published faster in West Sumatra than in West Java, i.e., the process was activated timely 2 weeks the after disaster and the documents were published less than 5 weeks after the earthquake, while in West Java, it was published after 7 weeks from the earthquake. In this sense, even when measured against current BNPB regulations (BNPB 2011), which at that time were not in operation, efforts in West Sumatra were already in compliance 
with the regulations. Humanitarian operations in West Sumatra also provided a strong base for recovery, mainly with its timely and high coverage of temporary shelter, while in West Java, even as of February 2010, people still reported living in tents. Further connectedness with the recovery plan saw preparation processes in West Sumatra being conducted jointly with other local stakeholders and international partners, while in West Java, only by the government. As a consequence, West Sumatra has greater organizational retention towards the recovery period, e.g., five out of seven ECB agencies remained on the field, more than 50 INGOs continued the recovery process, the humanitarian clusters transformed into working groups and legitimized by the government, and the early recovery efforts led legitimately and operationally by UNDP and Development Planning Agency of West Sumatra (Bappeda). While in West Java, only two out of seven ECB agencies remained, there was no clear role of clusters in recovery, and although early recovery was said to be led by UNDP, there was no clear coordination with the West Java government.

\section{Conclusions and recommendations}

This research, through SNA measurements and qualitative analysis, complements specific findings regarding the emergency response of the West Java Earthquake 2009 and the West Sumatra Earthquake 2009 made by Wilson (2010) and DARA (2010). Although both provinces have similar levels of organizational capacity, different approaches were taken in terms of how to orchestrate coordination and cooperation of emergency response and on statement of welcoming international assistance. By saying organizational capacity, it mainly refers to the fact that by September 2009, both provincial governments have not formed their BPBD and at the municipality level, their BPBDs were neither non-existence nor still infant. In West Java, BNPB supported centralization of coordination to Satkorlak West Java and initially neither requested for international assistance nor encouraged activation of the humanitarian cluster system, while in West Sumatra, from the very beginning, the provincial government and BNPB welcomed international assistance and instantly agreed on activating the humanitarian cluster system. Consequently, Satkorlak West Sumatra, under supervision from BNPB, worked in tandem with UNOCHA and other humanitarian cluster lead agencies. The network of inter-organizational cooperation formed on the ground is indeed not isolated from one another, i.e., the response in West Sumatra was also modified given the performance of emergency response in West Java. However, this research specifically compared networks in both cases, as a result of a conscious political decision by the government, as to test Gillmann's typology. By performing a lead-partnership mode of network which was comprised of all nine humanitarian clusters and activated timely, it was proven that humanitarian operations in West Sumatra performed better in all criteria of coherence, coverage, and connectedness.

This research, however, found a different conclusion than Gillmann's typology that the lead-agency type of network will always perform better if planned to be in operation; while at the same time supported Gillmann's pre-statement to her own typology that without adequate capacity and legitimacy of a lead agency, it is better to return and perform inter-organizational cooperation in emergency response activities by using the lead-partnership mode of network. Lastly, although still needing to be tested with other case studies, one of the possible implications from this research is that in a country or disaster-affected areas where the remaining governmental capacity exists but is still in infancy or developing their institutional capacity, lead partnership in humanitarian operations is better; while a lead-agency type of network led by UN agencies or NGOs is more appropriate for disaster situations and humanitarian operations where the remaining governmental capacity is weaker.

Given the findings of this research, the network of actors in a humanitarian operation should not only be fully associated with a lead-agency type of network but also can be strengthened in the operation through a lead-partnership type of network. Therefore, for some regulations in Indonesia, it is vital to add another criterion which regulates regarding at what level of disasters in association with the remaining local (or national) government capacity; thus, the command system for humanitarian operations will be implemented through a lead agency or a lead partnership, i.e., in relation to Indonesian Government Regulation 23/2008 regarding The Role of International Agencies and International Non-Government Organizations in Disaster Management, BNPB's Regulation Number 14/2010 regarding Guideline in Creating Command Post for Disaster Emergency Response, and BNPB's Regulation 22/2010 regarding the Role of the International Organization and Nongovernmental International Organizations during Emergency Response.

The same applies to the risk of regional-level disasters, for example, in the Southeast Asian region. Alternatives on whether to perform a lead-agency or a lead-partnership type of network in an emergency situation can enrich the detailed implementation of the ASEAN Coordinating Center for Humanitarian Assistance on disaster management (AHA Centre), on facilitating regional standby arrangements for disaster relief and emergency response. The AHA Centre is recommended to identify the level of disasters and the remaining capacity of the government in order to determine whether it should intervene as lead agency or maintain lead partnership among national governments in managing emergency response to regional-level disasters. Lastly, as can be learned from this research, basically, the 
humanitarian cluster arrangement functioned with various capacities and levels of engagement between international/ domestic and government/non-government actors. In the future, the various cluster arrangements should take into consideration when deciding whether the inter-cluster coordination should use lead-agency or lead-partnership type of network. Where in-country IASC exist, like in Indonesia, this consideration can be introduced to the inter-agency contingency plan managed by IASC.

For further scholarly purposes, the author would like to also recommend further research suggestions; first, there is merit to conduct research which detects networks of actors involved in not only humanitarian operations during emergency response but also those of which participated in disaster risk reduction and the development field in general, both before and after a disaster or the long-term recovery phase. Second, it is also recommended to conduct similar research for other types of disasters, especially with a slowonset disaster characteristic, e.g., volcanic eruptions and climate-related disasters, and politically sensitive humanitarian crises, such as domestic conflict or civil war. By doing so, a broader view can be seen whether the current system and organizations which are actively involved in disaster management are able to perform regardless of the disaster type. Third, the author would like to suggest the utilization of SNA for enriching the ongoing innovation of real-time evaluation (RTE) in disaster situations or humanitarian crises. At the same time, a better record of emergency response activities in all humanitarian clusters in an RTE will improve network modeling and will measure humanitarian aid delivery performance more accurately. Lastly, it is also worth to perform an ethnographic approach and network census in creating input for a dataset, i.e., not solely depending on recorded data in Situation Reports. With this, it will also be possible to distinguish between formal networks among organizations and informal network among agencies of organizations.

\section{Endnotes}

${ }^{1}$ Daily Report Pusdalops (Crisis Operation Center) BNPB-3 September 2009

${ }^{2}$ Summarized from Governor Decree SK 360/kep.1260-

Hukham/2009 on Emergency Response Status

${ }^{3}$ Daily Report Pusdalops (Crisis Operation Center) BNPB-4 September 2009

${ }^{4}$ West Java Earthquake 2009 Situation Report \#2, 3 September 2009, UNOCHA

${ }^{5}$ Interview with Key Person P, March 2012

${ }^{6}$ West Java Earthquake 2009 Situation Report \#3, 4 September 2009, UNOCHA

${ }^{7}$ Ibid

${ }^{8}$ Interview with Key Person X, March 2012

${ }^{9}$ Confirmed in interviews with Key Person D and Key

Person L, both in March 2012
${ }^{10}$ BNPB West Java Earthquake Situation Report 7 September 2009

${ }^{11}$ West Sumatra Earthquake 2009 Situation Report \#1 (UNOCHA 2009)

${ }^{12}$ West Sumatra Earthquake 2009 Situation Report \#8 (UNOCHA 2009)

${ }^{13}$ West Sumatra Earthquake 2009 Situation Report \#2 (UNOCHA 2009)

${ }^{14}$ In the interview with Key Person A in February 2013, after the earthquake, by 18:00, the provincial government started their first rapid assessment; thus, by 23:00, they sent a request to BNPB based on the assessment result, and later, by 03:00, the provincial government has set up a command center in the Governor's office and was ready to host incoming officials from the Central Government and UN Agencies.

${ }^{15}$ Confirmed in interviews with key person $\mathrm{A}, \mathrm{E}, \mathrm{T}$, and U in February 2013

${ }^{16}$ Summarized from documentation by Pranoto (2011) and West Sumatra Earthquake 2009 Situation Report \#3, UNOCHA

\section{Competing interests}

The author declares that he has no competing interests.

\section{Author's information}

Mizan Bustanul Fuady Bisri (Mizan) is a PhD Candidate in the Department of International Cooperation Policy Studies, Graduate School of International Cooperation Studies (GSICS), Kobe University, Japan. Prior to his PhD position, he received MA in political science from GSICS-Kobe University and M.Sc. in urban planning from Bandung Institute of Technology (ITB) in Indonesia. As a young scholar, Mizan has published several international academic articles, research reports, and a book chapter. He also has received several prestigious research grant and scholarship, such as Asian Development Bank-Japan Scholarship Program and UNOCHA Humanitarian Research and Innovation Grant Program in 2013. He is also assuming the position of Regional Focal Point for North and South East Asia in Disaster Risk Reduction at the United Nations Major Group for Children and Youth (UN-MGCY).

\section{Acknowledgements}

The author would like to acknowledge Professor Jun Matsunami of the Graduate School of International Cooperation Studies, Kobe University, Japan, for his guidance on this research and review on the manuscript. In addition, the author is also indebted to the Asian Development Bank-Japan Scholarship Program and later MEXT scholarship which facilitate author position in GSICS, Kobe University, and support the finance of the data gathering process and fieldwork for this research. Lastly, the author would like to extend gratitude to two blind-reviewers and the editor at the Journal of International Humanitarian Action, whose inputs contribute greatly to the improvement of this manuscript.

Received: 3 February 2016 Accepted: 10 June 2016

Published online: 07 July 2016

\footnotetext{
References

Bappenas (2009) Rencana Aksi Rehabilitasi dan Rekonstruksi Wilayah Pasca Gempa bumi di Provinsi Jawa Barat dan Kabupaten Cilacap, Provinsi Jawa Tengah 2 September 2009 (Action Plan Rehabilitation and Reconstruction of Post West Java Earthquake 2 September 2009). Bappenas (Ministry of Development Planning), Jakarta

Beck T (2006) Evaluating humanitarian action using the OECD-DAC criteria. ALNAP, London

Bisri MBF (2016) Observing Partnership Innovation through Inter-organizational Network Analysis on Emergency Response of the Great East Japan Earthquake and Tsunami 2011. Japan Social Innovation Journal, 27-41. doi.org/10.12668/jsij.6. 27. https://www.jstage.jst.go.jp/article/jsij/6/1/6_27/_pdf
} 
BNPB (2009) West Sumatra and Jambi natural disasters: damage, loss, and preliminary needs assessment. BNPB, Jakarta

BNPB (2011) Head of BNPB Regulation Number 15/2011 about guideline for post disaster need assessment. BNPB, Jakarta

Borgatti S, Everett MG, Freeman L (2002) Ucinet 6 for Windows: software for social network analysis. Analytic Technologies, Harvard

Brinkman H-J (2010) World Food Program: fighting hunger with an updated tool-box. WFP, Rome

Cahill K (2012) More with less: disasters in an era of diminishing resources. Fordham University Press, New York

Clarke PK, Campbell L (2015) Exploring coordination in humanitarian clusters. ALNAP/ODI, London

DARA (2010) Humanitarian Response Index 2010: crisis reports Indonesia. DARA, Madrid

Fredriksen A (2012) Making humanitarian spaces global: coordinating crisis response through the cluster approach. Columbia University, Graduate School of Arts and Sciences. Columbia University (Dissertation), New York

Gillmann N (2010) Interagency coordination during disaster: strategic choices for the UN, NGOs, and other humanitarian actors in the field. Nomos, Baden-Baden

Haines V, Hurlbert JS, Beggs JJ (1996) Exploring the determinants of support provision: provider characteristics, personal networks, community context, and support following life events. J Health Soc Behav 37(3):252-264

Hulbert JS, Beggs JJ, Haines V (2005) Bridges over troubled waters: what are the optimal networks for Katrina's victims? Social Science Research Council. Available via http://understandingkatrina.ssrc.org/Hurlbert_Beggs_Haines/. Accessed 10 Dec 2015.

IASC (2006) Guidance note on using the cluster approach to strengthen humanitarian approach. IASC (Inter-Agency Standing Committee), Geneva

IASC (2009) Indonesia Inter-Agency Contingency Plan. IASC (Inter-Agency Standing Committee), Jakarta

IFRC (2010) Operation update Indonesia: West Sumatra earthquakes. IFRC, Geneva

IFRC (2012) Shelter coordination in natural disasters. IFRC-International Federation of Red Cross and Red Crescent Societies, Geneva

Jasanoff S (2010) Beyond Calculation: a Democratic response to Risk. In A. Lakoff, Disaster and the Politics of Intervention. New York: Columbia University Press

Kapucu N, Arslan T, Collins ML (2010) Examining intergovernmental and interorganizational response to catastrophic disasters: towards a networkcentered approach. J Adm Soc 42(2):222-247

Kumar A (2011) Collaboration networks in disaster relief and humanitarian aid: a case study of Peru. Northwestern University (Master thesis), Illinois

Lakoff A (2010) Disaster and the politics of intervention. Columbia University Press, New York

Lassa J (2010) Institutional vulnerability and governance of disaster risk reduction: macro, meso, and micro scale assessment (with case studies from Indonesia). UNU - EHS (Dissertation), Bonn

Lassa J (2015) Post disaster governance, complexity and network theory: evidence from Aceh, Indonesia after the Indian Ocean Tsunami 2004. PLoS Curr Disasters. doi:10.1371/4f7972ecec1b6.

Moore S, Eng E, Daniel M (2003) International NGOs and the role of network centrality in humanitarian aid operation: a case study of coordination during the 2000 Mozambique floods. Disasters 27(4):305-318

Pranoto S (2011) Lessons Learned Pembelajaran Rehab Rekon Pasca Gempa di Sumatra Barat 30 September 2009 (Lessons learned rehabilitation and reconstruction in post West Sumatra Earthquake 2009). Pilar Karya, Padang

Prell C (2012) Social network analysis-history, theory, and methodology. Sage Publications, London

Roberts PS (2010) Private choices, public harms: the evolution of national disaster organizations in the United States. In: Lakoff A (ed) Disaster and the politics of intervention. Columbia University Press, New York

Salvatore D (2012) Globalization, growth, poverty, governance, and humanitarian assistance. In: Cahill KM (ed) More with less: disaster in era of diminishing resources. Fordham University Press, New York

Scott J (2000) Social Network Network Analysis. London: Sage Publications.

Taylor G, Stoddard A, Harmer A, Haver K, Harvey P, Barber K, Wilhelm C (2012) The State of the Humanitarian System 2012. ALNAP, London, Available via http://www.alnap.org/resource/6565. Accessed 20 Dec 2015

Tomassini R, Wassenhove LV (2009) Humanitarian logistics. Palgrave Macmillan, Londin

UNISDR (2015) Global Assessment Report on Disaster Risk Reduction 2015. UNISDR, Geneva
UNOCHA (2009) West Sumatra Earthquake 2009: humanitarian response plan. UNOCHA, Jakarta

Varda D, Forgette R, Banks D, Contractor N (2009) Social network methodology in the study of disasters: issues and insights prompted by post-Katrina research. Popul Resolution Policy Rev 28:11-29

Wasserman S, Faust K (1994). Social Network Analysis: Methods and Applications. Cambridge: Cambridge University Press.

Wilson P (2010) Report of the joint evaluation of the Indonesian ECB consortium's responses to the West Java and West Sumatra earthquakes. Indonesia Emergency Capacity Building Consortium, Jakarta, Available via http://www.alnap.org/resource/5957. Accessed 5 Dec 2015

\section{Submit your manuscript to a SpringerOpen ${ }^{\circ}$ journal and benefit from:}

- Convenient online submission

- Rigorous peer review

- Immediate publication on acceptance

- Open access: articles freely available online

- High visibility within the field

- Retaining the copyright to your article

Submit your next manuscript at springeropen.com 